\title{
The EIRA Database: Glacial to Holocene Radiocarbon Ages from Easter Island's Sedimentary Records
}

\author{
Valentí Rull * \\ Laboratory of Paleoecology, Institute of Earth Sciences Jaume Almera (ICTJA-CSIC), Barcelona, Spain
}

Keywords: Easter Island, Rapa Nui, lake sediments, mires, chronology, radiocarbon dating, Late Pleistocene, Holocene

\section{INTRODUCTION}

The archaeological and anthropological relevance of Easter Island (Rapa Nui) for human history in a regional Pacific context has been highlighted since the early twentieth century (Routledge, 1919). At first, the interest was focused on the giant stone statues called moai, which had been carved on the island's volcanic rocks by an enigmatic ancient civilization. The interest on the island received a boost several decades ago, after the expedition leaded by Thor Heyedahl (Heyerdahl and Ferdon, 1961) and the first palynological studies suggesting a recent ecological catastrophe, led by

Edited by:

Joel Guiot,

Centre National de la Recherche Scientifique, France

Reviewed by:

Maarten Blaauw,

Queen's University Belfast, UK Philippe Lanos,

Centre National de la Recherche

Scientifique, France

*Correspondence:

Valentí Rull

vrull@ictja.csic.es

Specialty section:

This article was submitted to

Paleoecology,

a section of the journal

Frontiers in Ecology and Evolution

Received: 26 February 2016

Accepted: 11 April 2016

Published: 26 April 2016

Citation:

Rull V (2016) The EIRA Database: Glacial to Holocene Radiocarbon Ages from Easter Island's Sedimentary Records. Front. Ecol. Evol. 4:44. doi: 10.3389/fevo.2016.00044 an abrupt island-wide deforestation likely due to the over-exploitation of natural resources, and an ensuing cultural collapse (Flenley and King, 1984; Flenley et al., 1991). This "ecocidal" theory became paradigmatic and the case of Easter Island was considered a microcosmic model for the whole planet and a warning against the uncontrolled use and of natural resources (Flenley and Bahn, 2003; Diamond, 2005). Further, archaeological and palaeoecological studies have challenged this ecocidal theory (Hunt and Lipo, 2006, 2011; Hunt, 2007; Lipo and Hunt, 2016), which has revitalized the debate on the recent cultural history of Easter Island (reviews in Rull et al., 2010, 2013).

In comparison to the concern for human developments and their influence on the island's environment, the palaeoclimatic history of Easter Island and its potential paleoecological consequences has received little attention until the last decade. Earlier palaeoecological studies emphasized the influence of human activities on vegetation and landscape shifts and undervalued the potential action of climatic changes as ecological drivers. This view was based on the continuity of forests, as reconstructed from pollen analysis, during the last $\sim 37,000$ years and their sudden disappearance and replacement by treeless meadows coinciding with the arrival of the first Polynesian settlers (Flenley and King, 1984; Flenley et al., 1991). The main argument was that the ecological effect of a global climatic shift as intense as for example the Last Glacial Maximum (LGM) was negligible as compared to the ecological changes induced by anthropogenic activities during the last millennium. Propositions suggesting a potential influence of climatic shifts such as the Little Ice Age (LIA) or the ENSO variability on Easter Island's ecological and cultural history (Hunter-Anderson, 1998; McCall, 1993; Nunn, 2000, 2007; Nunn and Britton, 2001; Nunn et al., 2007; Stenseth and Voje, 2009) were dismissed as they were mostly based on theoretical assumptions without empirical support. Recent palaeoecological studies are changing this view by documenting significant climatic shifts and their influence on ecological patterns and processes during the last 70,000 years (e.g., Mann et al., 2008; Sáez et al., 2009; Cañellas-Boltà et al., 2012, 2013; Margalef et al., 2013, 2014). 
Since the beginning, the paleoclimatic and palaeoecological study of Easter Island has faced a persistent drawback caused by the occurrence of dating inconsistencies, mainly extensive chronostratigraphic gaps and frequent age inversions (Butler et al., 2004; Rull et al., 2013). These inconsistencies have prevented the development of reliable age-depth models in many cases, especially in Holocene intervals including the last millennia, thus preventing researchers to disentangle climatic and anthropogenic causes of ecological change, which is essential for incorporating palaeoecological and palaeoclimatic trends into predictive models. In the past, age-depth models were relatively simple and consisted mainly of interpolations and extrapolations assuming linear sedimentation rates between adjacent dating points. Dates that significantly deviated from this trend were usually rejected and not included in the model. Further improvements consisted of curve fitting using linear, exponential, logarithmic, or polynomial models, among others, which enable the calculation of statistical errors for the estimated ages. Recently, new approaches using a variety of methods, including Bayesian analysis, have been developed (e.g., Blaauw, 2010; Blaauw and Christen, 2011). In Easter Island, these new methods have been applied to the new cores obtained in the last years but historical dates and age-depth models have not been reconsidered in light of these new statistical developments.

Statistical re-analyses of the existing radiocarbon dates may provide new insights on Easter Island's chronostratigraphy useful to strengthen paleoclimatic and paleoecological inferences. In order to facilitate this type of investigation, a dataset called EIRA (Easter Island Radiocarbon Ages) has been assembled with all the radiocarbon dates published to date (1984-2015). The EIRA database provides paleoecologists and paleoclimatologists with a thorough chronological dataset to be analyzed statistically as a whole or by parts (by sites, by age intervals, etc.), aimed at contributing to the development of new age-depth models, reconsider the existing ones, or plan new studies and coring campaigns. It would be especially interesting to test whether it is possible to derive site-specific or island-wide coherent chronostratigraphic patterns by multi-core age-depth modeling. Also, further analyses of the EIRA database in comparison with recent compilations of radiocarbon ages from archaeological materials (e.g., Vargas et al., 2006; Wilmshurst et al., 2011; Mulrooney, 2013; Stevenson et al., 2015; Lipo and Hunt, 2016), could contribute to improve correlations among climatic, ecological, and cultural trends toward a holistic framework for Easter Island's history (Rull et al., 2016).

\section{METHODS}

\section{Study Area and Coring Sites}

Easter Island is a volcanic island located in the southeastern Pacific Ocean, at $27^{\circ} 07^{\prime} 16^{\prime \prime}$ Lat $\mathrm{N}$ and $109^{\circ} 21^{\prime} 59^{\prime \prime}$ Long W (Figure 1), at $>3500 \mathrm{~km}$ of the American continent and $\sim 2100$ $\mathrm{km}$ of the nearest inhabited Polynesian island (Pitcairn). The island $\left(164 \mathrm{~km}^{2}\right)$ defines a small triangle originated by the fusion of three volcanic cones (Terevaka, Poike, and Kao). The highest point of the island is the summit of the Maunga Terevaka, situated at $511 \mathrm{~m}$ elevation. Easter Island's volcanic rocks are highly porous and precipitation infiltrates easily through them thus preventing the formation of surface stream flow. The only permanent sources of freshwater are two lakes (Rano Kao and Rano Raraku) and a mire (Rano Aroi), which contain the sediments where all palaeoecological studies conducted so far have been developed.

Rano Aroi is a mire of $\sim 150 \mathrm{~m}$ diameter situated at $430 \mathrm{~m}$ elevation within a crater near the highest summit of the island (Figure 1). Water level is controlled by groundwater inputs subjected to the influence of seasonal variations in precipitation and human extraction (Herrera and Custodio, 2008). The aquatic vegetation is dominated by Scirpus californicus, Polygonum acuminatum, and ferns of the genera Asplenium, Vittaria, and Cyclosorus, whereas the surrounding area is covered by grasslands and a small Eucalyptus forest planted during the 1960s (Zizka, 1991). The mire infilling is predominantly peat and is at least $16 \mathrm{~m}$ deep in the center, which represents an age of approximately 70,000 cal y BP (Margalef et al., 2013, 2014). Flenley et al. (1991) described this organic accumulation as a mixture of coarse detritus and finer material intermingled with layers of spongy monocotyledonous peat and brown clay. Peteet et al. (2003) reported the occurrence of several types of peats and organic clays with fibrous material. A similar composition was described by Horrocks et al. (2015). Margalef et al. (2013, 2014) did a detailed lithological study and distinguished four main organic facies: (A) reddish peat of sedges and Polygonum; (B) granulated muddy peat of coarse organic fragments, mainly roots, with low terrigenous content; (C) organic mud or darkbrown to black peat; and (D) dark-brown fine-grained peat. Facies $\mathrm{B}$ is the more common throughout the sequence. This mire has been cored several times between 1977 and 2009, and five of the cores obtained have been radiocarbon dated (Figure 1). An additional core was retrieved and dated in a nearby small depression, Rano Aroi Iti, in 2009. The original data and methodological details are in Flenley (1979), Flenley and King (1984), Flenley et al. (1991), Peteet et al. (2003), Margalef (2014), Margalef et al. (2013, 2014), Rull et al. (2015), Horrocks et al. (2015).

Rano Kao contains the largest lake of the island, with $\sim 1250 \mathrm{~m}$ diameter, situated at $110 \mathrm{~m}$ elevation (Figure 1). This lake is very peculiar as its surface is a mosaic of water and aquatic vegetation in the form of floating mats up to $3 \mathrm{~m}$ deep overlying the water column, which is up to $10 \mathrm{~m}$ deep. The oldest ages recorded so far in the floating mat are around 700-900 cal yr BP (Gossen, 2007; Horrocks et al., 2013). Therefore, during roughly the last millennium past ecological and environmental evidence has been accumulating in both the floating peats and the upper layer of lake sediments. It has been suggested that these two archives would have been partially mixed by immersion of mat fragments thus causing chronological anomalies, typically age inversions, in the sedimentary sequence (Butler et al., 2004). The floating mats are dominated by the characteristic aquatic species of the island, $S$. californicus and P. acuminatum, together with another sedge, Pychreus polystachius (Zizka, 1991). A significant number of archaeological sites have been found around Rano Kao, notably the ancient village of Orongo, which is one of the more important and well preserved archaeological 

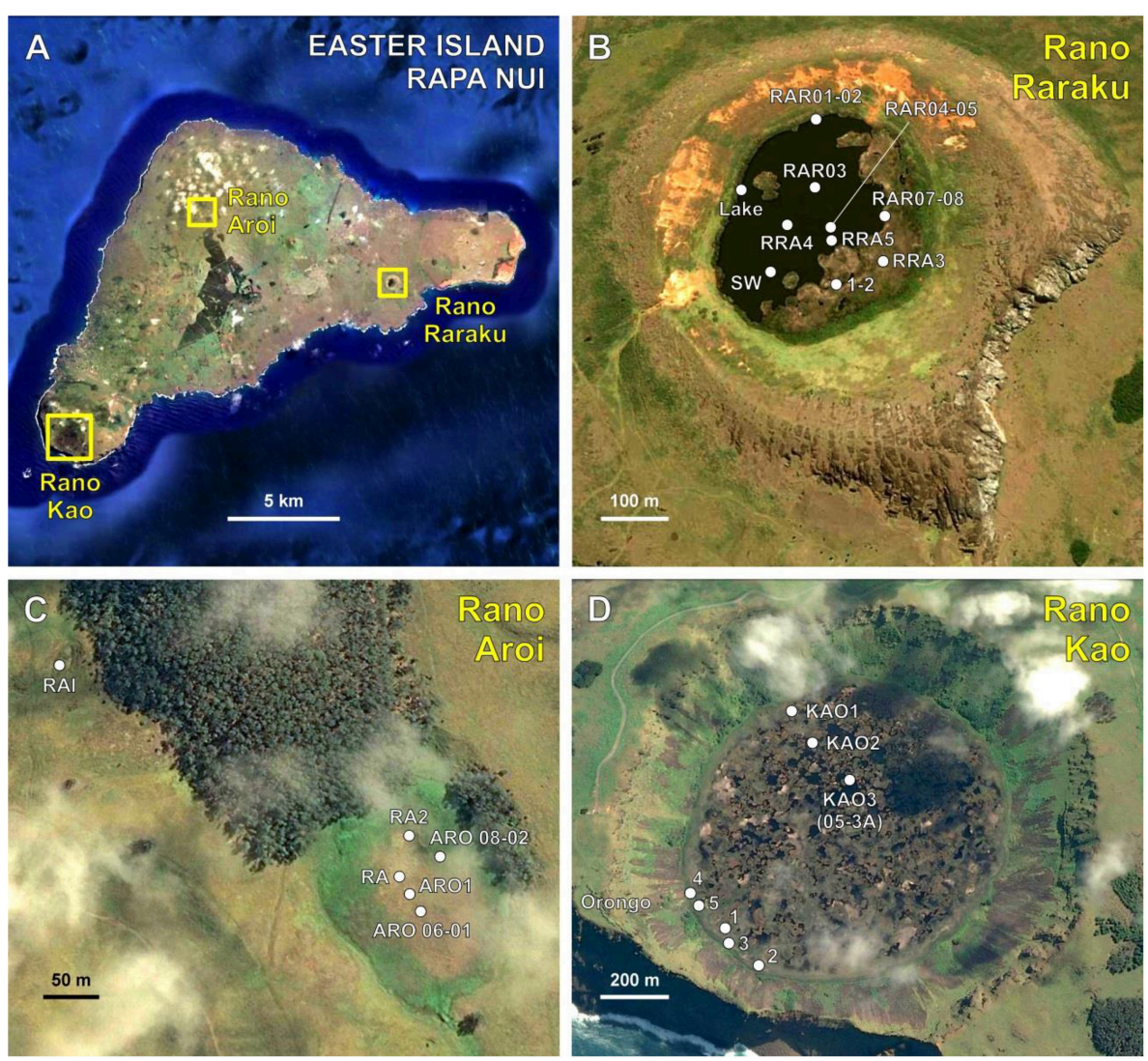

FIGURE 1 | Google Earth images of the lakes and mire studied, indicating the location of the cores from which radiocarbon ages originate. (A) Location of the lakes/mires, (B) Lake Raraku, (C) Aroi mire, (D) Lake Kao.

complexes of the island. The maximum depth of lake sediments recorded thus far is $\sim 21 \mathrm{~m}$ and the maximum age measured is $\sim 34,000 \mathrm{cal}$ yr BP (Gossen, 2007, 2011; Horrocks et al., 2013). The Kao lake sediments have been described as coarse organic detritus derived from aquatic and catchment vegetation, with a basal layer of coarse detritus and clay (Flenley and King, 1984; Flenley et al., 1991; Horrocks et al., 2013). This lake was cored between 1977 and 2005. Eight of the cores retrieved were radiocarbon dated and are included in this compilation. The following references contain the original data and methodological details: Flenley (1996), Butler and Flenley (2001, 2010), Butler et al. (2004), Gossen (2007, 2011), Horrocks et al. (2012b, 2013).

Rano Raraku contains a lake of intermediate size $(\sim 300 \mathrm{~m}$ diameter), situated at $80 \mathrm{~m}$ elevation (Figure 1). Hydrologically, the lake is closed, with no surface outlet, and is used by humans as a freshwater source for consumption and irrigation. The main water inputs are rainfall and catchment runoff (Herrera and Custodio, 2008). The maximum water depth recorded in modern times is $\sim 3 \mathrm{~m}$ (Sáez et al., 2009). The aquatic vegetation is dominated by $S$. californicus, which forms a more or less continuous floating belt in the east margin of the lake. Rano Raraku is one of the more emblematic sites of the island as it was the quarry where the moai were sculptured. The sedimentary infilling is at least $14 \mathrm{~m}$ deep in the center of the lake, which corresponds to an age of $34,000 \mathrm{cal}$ yr BP (Sáez et al., 2009). These sediments have been described as a mixture of coarse and fine detritus originating from lake and catchment vegetation, intermingled with layers of gyttja, clay, and mud and, occasionally, volcanic ashes (Flenley et al., 1991; Horrocks et al., 2012a). A more detailed sedimentological study reported that the Raraku sediments were dominated by organic matter with variable amounts of terrigenous mineral particles from the catchment rocks. The organic matter was a mixture of plant remains from the catchment and, in lower proportion, autochthonous organic matter derived from lake production (Sáez et al., 2009). The same study distinguished four sedimentary facies: (1) laminated, dark gray-reddish organic-rich silts and mud; (2) laminated and massive brownish organic mud; (3) brown-reddish massive or banded peaty sediment, composed mainly of plant (sedge) remains; and (4) peat and silty clay. These sediments have been cored between 1977 and 2009, with 14 cores having radiocarbon dates (Figure 1). The raw palaeoecological and palaeoclimatic information from these cores is in Flenley (1979), Flenley and King (1984), Flenley et al. (1991), Dumont et al. (1998), Azizi and Flenley (2008), Sáez et al. (2009), Horrocks et al. (2012a), Cañellas-Boltà (2014), and Cañellas-Boltà et al. (2012, 2013, 2014). 


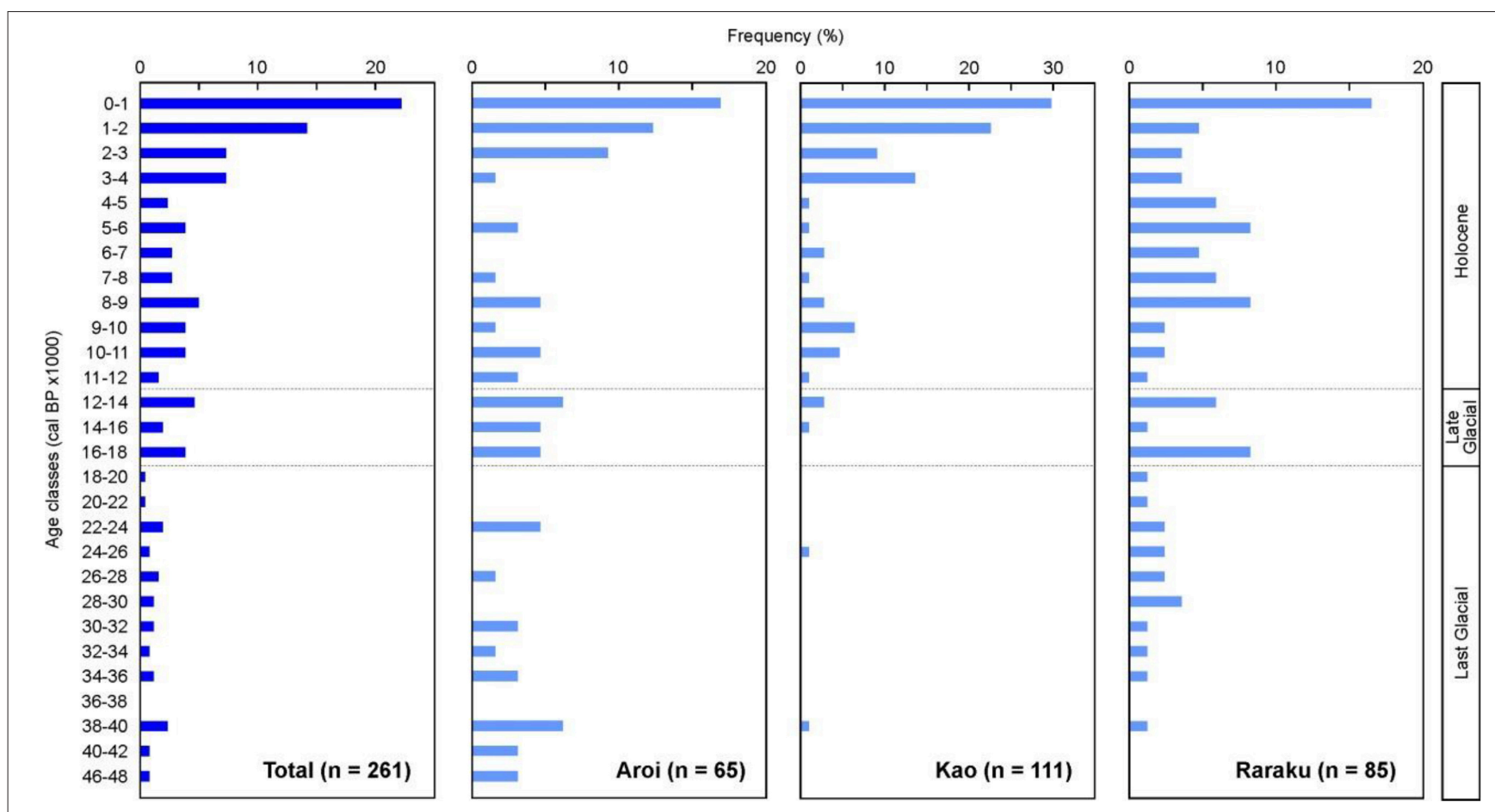

FIGURE 2 | Histogram with the distribution of radiocarbon ages by time intervals. Only calibrated ages (median probability) have been considered.

Raw data in the Supplementary Material.

\section{The Dataset}

The EIRA database contains all the radiocarbon ages from Aroi, Kao, and Raraku sediments published to date (1984-2015). In order to preserve objectivity, all radiocarbon dates from all the cores dated by this method have been included in this compilation, regardless of whether the original authors have considered them in their age-depth models or not. The raw ${ }^{14} \mathrm{C}$ data are exactly as they appear in the original references, except for post-bomb ages, which are given as negative ${ }^{14} \mathrm{C}$ ages for homogeneity. Whenever, possible-i.e., when all the necessary data were available and the dates are within the age range for radiocarbon dating- the original radiocarbon ages have been calibrated or re-calibrated with CALIB 7.1 (http:// calib.qub.ac.uk/calib/) using the SHCal13 curve (Hogg et al., 2013). Post-bomb (negative) ${ }^{14} \mathrm{C}$ ages were calibrated with clam 2.2 (Blaauw, 2010; http://chrono.qub.ac.uk/blaauw/clam.html), using the curve SH zone 1-2 (Hua et al., 2013). The database is provided in the Supplementary Material as an Excel file (EIRAdb 2.5), which is also freely available at the NOAA International Climatic Data Center, section Paleoclimate, under the accession number 19805 (https://www.ncdc.noaa.gov/paleo/study/19805).

The Excel file consists of four sheets named cores, data, lab codes, and references, respectively. The core sheet contains the cores from which dated samples proceed, with the following information arranged in columns: site name (lake/bog), site coordinates (at the center of each site), elevation, core name, core coordinates, water depth at the coring site, core length, date retrieved, coring system, and references from where these data were obtained. The data sheet displays the radiocarbon dates organized in the following columns: site, core, references, sample code assigned by the corresponding radiocarbon laboratory, sample depth (top, base, and average), material dated, ${ }^{14} \mathrm{C}$ date, dating error, calibrated dates at 95\% probability ranges (maximum and minimum), median probability and observations. In some cases, only calibrated age ranges are provided because they appear in this form in the original references. ND means "No Data." The third sheet, lab codes, provides the identification of each radiocarbon laboratory according to their acronyms and the fourth sheet contains the references cited in sheets one (cores) and two (data). The current version (2.5) of this file was validated March 31, 2016 and will be updated and uploaded to the NOAA repository each year.

The total number of radiocarbon ages is 279 , corresponding to 28 cores, ranging from ca. 48,000 to the present. The number of calibrated dates is 261, distributed as follows: Aroi, 65 dates; Kao, 111 dates, and Raraku, 85 dates. Overall, most dates correspond to the Holocene, especially to the last two millennia, which is the period most intensively studied due to its cultural relevance (Figure 2). In contrast, the period between 4000 and $8000 \mathrm{cal}$ yr BP is the least represented. This is true for Aroi and Kao but not for Raraku, where this early-middle Holocene interval is well represented. In general, Late Glacial ages are intermediate in frequency but they are also irregularly distributed among sites, as they are fairly well represented in Aroi and Raraku but not in Kao. Last Glacial dates are the least represented, especially in the interval corresponding to the LGM $(18,000-22,000 \mathrm{cal}$ 
yr BP), which is represented only in Raraku. Noteworthy, Pleistocene ages are almost absent in Kao. Whether the paucity of specific age intervals is due to the scarcity of sediments of these ages, which may help identifying eventual sedimentary gaps, or to differential sampling effort, is worth to be analyzed for its potential significance in terms of local and island-wide sedimentation patterns.

\section{AUTHOR CONTRIBUTIONS}

The author confirms being the sole contributor of this work and approved it for publication.

\section{REFERENCES}

Azizi, G., and Flenley, J. R. (2008). The last glacial maximum climatic conditions on Easter Island. Quat. Int. 184, 166-176. doi: 10.1016/j.quaint.2007.09.027

Blaauw, M. (2010). Methods and code for 'classical' age-modelling of radiocarbon sequences. Quat. Geochronol. 5, 512-518. doi: 10.1016/j.quageo.2010.01.002

Blaauw, M., and Christen, J. A. (2011). Flexible paleoclimate age-depth models using an autoregressive gamma process. Bayesian Anal. 6, 457-474. doi: $10.1214 / \mathrm{ba} / 1339616472$

Butler, K., and Flenley, J. (2001). "Further pollen evidence from Easter Island," in Pacific 2000. Proceedings of the Fifth International Conference on Easter Island and the Pacific, eds C. M. Stevenson, G. Lee, and F. J. Morin (Los Osos, CA: Easter Island Foundation), 79-86.

Butler, K., and Flenley, J. R. (2010). The Rano Kau 2 pollen diagram: palaeoecology revealed. Rapa Nui J. 24, 5-10.

Butler, K., Prior, C. A., and Flenley, J. (2004). Anomalous radiocarbon dates from Easter Island. Radiocarbon 46, 395-405.

Cañellas-Boltà, N. (2014). Vegetation Dynamics in Relation to Climate Changes, Geological Processes, and Human Impact at Easter Island Since the Last Glacial. Paleoecological Study of Sediments from Lake Raraku. Dissertation/Ph.D. thesis, University of Barcelona, Barcelona.

Cañellas-Boltà, N., Rull, V., Sáez, A., Margalef, O., Bao, R., Pla-Rabes, S., et al. (2013). Vegetation changes and human settlement of Easter Island during the last millennia: a multiproxy study of Lake Raraku sediments. Quat. Sci. Rev. 72, 36-48. doi: 10.1016/j.quascirev.2013.04.004

Cañellas-Boltà, N., Rull, V., Sáez, A., Margalef, O., Giralt, S., Pueyo, J. J., et al. (2012). Macrofossils in Raraku Lake (Easter Island) integrated with sedimentary and geochemical records: towards a palaeoecological synthesis of the last 34,000 years. Quat. Sci. Rev. 34, 113-126. doi: 10.1016/j.quascirev.2011.12.013

Cañellas-Boltà, N., Rull, V., Sáez, A., Prebble, M., and Margalef, O. (2014). First records and potential palaeoecological significance of Dianella (Xanthorrhoeaceae), an extinct representative of the native flora of Rapa nui (Easter Island). Veg. Hist. Archaeobot. 23, 331-338. doi: $10.1007 / \mathrm{s} 00334-014-0432-8$

Diamond, J. (2005). Collapse. How Societies Choose to Fail or Survive. London: Allen Lane.

Dumont, H. J., Cocquyt, C., Fontugne, M., Arnold, M., Reyss, J.-L., Bloemendal, J., et al. (1998). The end of quarrying and its effect on Lake Raraku, Easter Island. J. Paleolimnol. 20, 409-422. doi: 10.1023/A:1008012720960

Flenley, J. R. (1979). Stratigraphic evidence of environmental change on Easter Island. Asian Persp. 22, 33-40.

Flenley, J. R. (1996). Further evidence of vegetation change on Easter Island. South Pacific Stusy 16, 135-141.

Flenley, J. R., and Bahn, P. (2003). The Enigmas of Easter Island. Oxford: Oxford University Press.

Flenley, J. R., King, A. S. M., Jackson, J., Chew, C., Teller, J. T., and Prentice, M. E. (1991). The late quaternary vegetational and climatic history of Easter Island. J. Quat. Sci. 6, 85-115. doi: 10.1002/jqs.3390060202

Flenley, J. R., and King, S. M. (1984). Late quaternary pollen records from Easter Island. Nature 307, 47-50. doi: 10.1038/307047a0

\section{ACKNOWLEDGMENTS}

Funding for publication fees was provided by the Catalan Agency for Management of University and Research Grants (AGAUR), grant GCR 2014-SGR-1207. Discussions with S. Giralt and A. Sáez contributed to clarify the potential uses and limitations of the database.

\section{SUPPLEMENTARY MATERIAL}

The Supplementary Material for this article can be found online at: http://journal.frontiersin.org/article/10.3389/fevo. 2016.00044

Gossen, C. (2007). Report: the mystery lies in the Scirpus. Rapa Nui J. 21, 105-110. Gossen, C. (2011). Deforestation, Drought and Humans: New Discoveries of the Late Quaternary Paleoenvironment of Rapa Nui (Easter Island). Dissertation/Ph.D. thesis, Portland State University, Portland, OR.

Herrera, C., and Custodio, E. (2008). Conceptual hydrological model of volcanic Easter Island (Chile) after chemical and isotopic surveys. Hydrogeol. J. 16, 1329-1348. doi: 10.1007/s10040-008-0316-Z

Heyerdahl, T., and Ferdon, E. (1961). Reports of the Norwegian Archaeological Expedition to Easter Island and the East Pacific. London: Allen \& Unwin.

Hogg, A. G., Hua, Q., Blackwell, P. G., Niu, M., Buck, C. E., Guilderson, T. P., et al. (2013). SHCal13 Southern Hemisphere calibration, 0-50,000 years cal BP. Radiocarbon 55, 1889-1993. doi: 10.2458/azu_js_rc.55.16783

Horrocks, M., Baisden, W. T., Flenley, J., Feek, D., González Nualart, L., HaoaCardinali, S., et al. (2012a). Fossil plant remains at Rano Raraku, Easter Island's statue quarry: evidence for past elevated lake level and ancient Polynesian agriculture. J. Paleolimnol. 48, 767-783. doi: 10.1007/s10933-012-9643-0

Horrocks, M., Baisden, W. T., Harper, M. A., Marra, M., Flenley, J., Feek, D., et al. (2015). A plant microfossil record of Late Quaternary environments and human activity from Rano Aroi and surroundings, Easter Island. J. Paleolimnol. 54, 279-303. doi: 10.1007/s10933-015-9852-4

Horrocks, M., Baisden, W. T., Nieuwoudt, M. K., Flenley, J., Feek, D., González Nualart, L., et al. (2012b). Microfossils of polynesian cultigens in lake sediment cores from Rano Kau, Easter Island. J. Paleolimnol. 47, 185-204. doi: 10.1007/s10933-011-9570-5

Horrocks, M., Marra, M., Baisden, W. T., Flenley, J., Feek, D., González Nualart, L., et al. (2013). Pollen, phytoliths, arthropods and high-resolution 14C sampling from Rano Kau, Easter Island: evidence for late Quaternary environments, ant (Formicidae) distributions and human activity. J. Paleolimnol. 50, 417-432. doi: 10.1007/s10933-013-9735-5

Hua, Q., Barbetti, M., and Rakowski, A. Z. (2013). Atmospheric radiocarbon for the period 1950-2010. Radiocarbon 55, 2059-2072. doi: 10.2458/azu_js_rc.v55i2.16177

Hunt, T. L. (2007). Rethinking Easter island's ecological catastrophe. J. Archaeol. Sci. 34, 485-502. doi: 10.1016/j.jas.2006.10.003

Hunt, T. L., and Lipo, C. P. (2006). Late colonization of Easter Island. Science 311, 1603-1606. doi: 10.1126/science.1121879

Hunt, T. L., and Lipo, C. P. (2011). The Statues that Walked. New York, NY: Free Press.

Hunter-Anderson, R. L. (1998). "Human vs. climatic impacts at Rapa Nui, Did people really cut down all those trees?", in Easter Island in Pacific context - South Seas Symposium, eds C. M. Stevenson, G. Lee, and F. J. Morin (Los Osos, CA: Easter Island Foundation), 95-99.

Lipo, C. P., and Hunt, T. L. (2016). "Chronology and Easter Island prehistory," in Skeletal Biology of the Ancient Rapanui (Easter Islanders), eds V. H. Stefan and G. W. Gill (Cambridge, Cambridge University Press), 40-65.

Mann, D., Edwards, J., Chase, J., Beck, W., Reanier, R., Mass, M., et al. (2008). Drought, vegetation change, and human history on Rapa Nui (Isla de Pascua, Easter Island). Quat. Res. 69, 16-28. doi: 10.1016/j.yqres.2007.10.009

Margalef, O. (2014). The Last 70 kyr of Rano Aroi (Easter Island, 27 $\mathrm{S}$ ) Peat Record: New Insights for the Central Pacific Paleoclimatology. Dissertation/Ph.D. thesis, University of Barcelona, Barcelona. 
Margalef, O., Cañellas-Boltà, N., Pla-Rabes, S., Giralt, S., Pueyo, J. J., Joosten, H., et al. (2013). A 70,000 year multiproxy record of climatic and environmental change from Rano Aroi peatland (Easter Island). Glob. Planet. Change 108, 72-84. doi: 10.1016/j.gloplacha.2013.05.016

Margalef, O., Martínez-Cortizas, A., Kylander, M., Pla-Rabes, S., CañellasBolt,à, N., Pueyo, J. J., et al. (2014). Environmental processes in Rano Aroi (Easter Island) peat geochemistry forced by climate variability during the last 70 kyr. Palaeogeogr. Palaoeclimatol. Palaeoecol. 414, 438-450. doi: 10.1016/j.palaeo.2014.09.025

McCall, G. (1993). Little Ice Age, some speculations for Rapanui. Rapa Nui J. 7, 65-70.

Mulrooney, M. (2013). An island-wide assessment of the chronology of settlement and land use on Rapa Nui (Easter Island) based on radiocarbon data. J. Archaeol. Sci. 40, 4377-4399. doi: 10.1016/j.jas.2013. 06.020

Nunn, P. D. (2000). Environmental catastrophe in the Pacific islands around A.D. 1300. Geoarchaeol. 15, 715-740. doi: 10.1002/15206548(200010)15:7<715::AID-GEA4>3.0.CO;2-L

Nunn, P. D. (2007). Climate, Environment and Society in the Pacific During the Last Millennium. Amsterdam: Elsevier.

Nunn, P. D., and Britton, J. M. R. (2001). Human-environment relationships in the Pacific islands around A.D. 1300. Environ. Hist. 7, 3-22. doi: $10.3197 / 096734001129342388$

Nunn, P. D., Hunter-Anderson, R., Carson, M. T., Thomas, F., Ulm, S., and Rowland, M. J. (2007). Times of plenty, times of less: last millennium societal disruption in the Pacific Basin. Hum. Ecol. 35, 385-401. doi: 10.1007/s10745006-9090-5

Peteet, D., Beck, W., Ortiz, J., O’Connell, S., Kurdyla, D., and Mann, D. (2003). "Rapid vegetational and sediment change from Rano Aroi crater, Easter Island," in Easter Island. Scientific Exploration into the World's Environmental Problems in Microcosm, eds J. Loret and J. T. Tanacredi (New York, NY: Kluwer Academic/Plenum Publishers), 81-93.

Routledge, K. (1919). The Mystery of Easter Island: The Story of an Expedition. London: Sifton, Praed \& Co.

Rull, V., Cañellas-Boltà, N., Margalef, O., Pla-Rabes, S., Sáez, A., and Giralt, S. (2016). Three millennia of climatic, ecological and cultural change on Easter Island: an integrative overview. Front. Ecol. Evol. 4:29. doi: 10.3389/fevo.2016.00029

Rull, V., Cañellas-Boltà, N., Margalef, O., Sáez, A., Pla-Rabes, S., and Giralt, S. (2015). Late Holocene vegetation dynamics and deforestation in Rano Aroi: implications for Easter Island's ecological and cultural history. Quat. Sci. Rev. 126, 219-226. doi: 10.1016/j.quascirev.2015.09.008

Rull, V., Cañellas-Boltà, N., Sáez, A., Giralt, A., Pla, S., and Margalef, O. (2010). Paleoecology of Easter Island: evidence and uncertainties. Earth-Sci. Rev. 99, 50-60. doi: 10.1016/j.earscirev.2010.02.003

Rull, V., Cañellas-Boltà, N., Sáez, A., Margalef, O., Bao, R., Pla-Rabes, S., et al. (2013). Challenging Easter Island's collapse: the need for archaeologicalpalaeoecological synergies. Front. Ecol. Evol. 2:56. doi: 10.3389/fevo.2013. 00003

Sáez, A., Valero-Garcés, B., Giralt, S., Moreno, A., Bao, R., Pueyo, J. J., et al. (2009). Glacial to Holocene climate changes in the SE Pacific. The Raraku Lake sedimentary record (Easter Island, $27^{\circ}$ S). Quat. Sci. Rev. 28, 2743-2759. doi: 10.1016/j.quascirev.2009.06.018

Stenseth, N. C., and Voje, K. L. (2009). Easter Island: climate change may have contributed to past cultural and societal changes. Clim. Res. 39, 111-114. doi: 10.3354/cr00809

Stevenson, C. M., Puleston, C. O., Vitousek, P. M., Chadwick, O. A., Haoa, S., and Ladefoged, T. N. (2015). Variation in Rapa Nui (Easter Island) land use indicates production and population peaks prior to European contact. Proc. Natl. Acad. Sci. U.S.A. 112, 1025-1030. doi: 10.1073/pnas.14207 12112

Vargas, P., Cristino, C., and Izaurieta, R. (2006). 1000 Años en Rapa Nui. Arqueología del asentamiento. Santiago: Ed. Universitaria.

Wilmshurst, J. M., Hunt, T. L., Lipo, C. P., and Anderson, A. J. (2011). Highprecision radiocarbon dating shows recent and rapid initial colonization of east Polynesia. Proc. Natl. Acad. Sci. U.S.A. 108, 1815-1820. doi: $10.1073 /$ pnas. 1015876108

Zizka, G. (1991). Flowering plants of Easter Island. Palmarum Hortus Francofurtensis Sci. Rep. 3, 1-108.

Conflict of Interest Statement: The author declares that the research was conducted in the absence of any commercial or financial relationships that could be construed as a potential conflict of interest.

Copyright (c) 2016 Rull. This is an open-access article distributed under the terms of the Creative Commons Attribution License (CC BY). The use, distribution or reproduction in other forums is permitted, provided the original author (s) or licensor are credited and that the original publication in this journal is cited, in accordance with accepted academic practice. No use, distribution or reproduction is permitted which does not comply with these terms. 